\title{
An Application of KMV Model to Forecast the Credit Risk of Corporate Customers and Bank's Expected Losses
}

\author{
NGUYEN THI CANH \\ University of Economics and Law - Vietnam National University HCMC - canhnt@uel.edu.vn \\ PHAM CHI KHOA \\ University of Economics and Law - Vietnam National University HCMC - khoapc@uel.edu.vn
}

\section{ARTICLE INFO ABSTRACT}

Article history:

Received:

Aug. 302014

Received in revised form

Oct. 292014

Accepted:

Dec. 302014

Keywords:

KMV model, default point, distance to default, default probability, extent of loss, corporate customers.
The research aims to apply KMV-Merton model to calculate and forecast default probability (DP) among corporate customers of Vietcombank. Analyzing data from financial statements of 6,398 corporate customers in the years 2008-2012/2013, the research shows that the DP of the whole customer portfolio is $2.6 \%$, equaling a loss of VND6,319 billion, or 3.8\% of outstanding loans to the portfolio. The results also show that small-sized companies have smaller DP as compared to larger ones. Regarding industries, the lowest DP is found in road and waterway transport business, and the highest is in electricity (including production, transmission and distribution), production of other kinds of power, and seafood processing business. Industries with high DP and outstanding loans may cause the greatest damage to banks. The research concludes that large-sized companies and seafood processing enterprises cause the greatest losses to banks. 


\section{Introduction}

The world economy has been struck by numerous crises, which result in the rising toll of bankcruptcies, crumbling banking systems, and economic slowdown. Since 2008 Vietnam has endured a particularly tough time when multiple small- and medium-sized enterprises went bankruptcy and an increase in bad debt that causes great difficulties for commercial banks, and many of them are trying hard to solve their huge debts. This is a source of problems confronting banks' risk management. If banks' asssessment of debt servicing ability through credit rating and their forecasts for customers'default are accurate, then perhaps bad debt or credit risk will be well controlled, and losses will be reduced. Multinational financial corporations and banks in developed countries usually utilize teams of specialists capable of manipulating mathematical models in analyzing credit risk and have succeeded in minimizing dramatic losses.

Vietnam's commercial banks over the past years have made efforts to apply and develop their own methods of estimating and controlling consumers' debt servicing ability. However, there were not many empirical researches as well as practical applications of modern statistical techniques to evaluate Vietnamese bank credit risks. In this circumstance the paper presents an application of classical KMV model with a few adjustments to best suit Vietnam's conditions in predicting credit risk of corporate customers and potential losses suffered when risks occur. As with KMV model, the authors use data from financial statements of enterprises (defined as corporate customers included in loan portfolio of Vietcombank between 2008 and 2012/2013[1]) for the forecast.

\section{Theories and literature review}

\subsection{Classical KMV-Merton model}

Pioneered in 1974, KMV-Merton model was based on the Black and Scholes option pricing theory and other key hypotheses formulated by Merton (1974). Shortly afterward, KMV developed the classical Merton model for enterprise default forecast and thereby came up with KMV-Merton as a model. It is established on the thought that equity capital of an enterprise can be viewed as a call option on asset value in a certain period of time. Once asset value falls below default point at or before the end of the period considered, default immediately ensues. In simple terms, 
KMV-Merton model allows for the awareness of enterprise default probability in the selected sample at any given time and takes into account two particularly noticeable assumptions:

(1) Total asset of a firm can be described by Geometric Brownian Motion:

$\mathrm{dV}=\mu \mathrm{Vdt}+\sigma_{\mathrm{V}} \mathrm{VdW}$

where:

V: firm's total assets;

$\mu$ : instantaneous expected return rate of $\mathrm{V}$;

$\sigma_{\mathrm{v}}$ : volatility of firm's value; and

$\mathrm{dW}$ : standard Wiener process [2]

(2) The firm is only burdened with one type of debt, comprising a zero-coupon bond that matures at time $\mathrm{T}$.

Based on these two key assumptions, value of firm's equity can be regarded as a call option on the assets which is firm's total assets with exercise price equalling market value of the debt at maturity time $\mathrm{T}$.

Furthermore, the relationship between call and put options results in the inference that the market value of firm's debt equals the value of risk-free bonds without the payment of periodic interest issued by firm with real value being debt par value and time-to-maturity of T minus put option to firm's asset value.

Based on the above KMV-Merton's theory, the formula used to calculate value of firm's equity is as follows:

$$
\mathrm{E}=\mathrm{V} \cdot \mathrm{N}\left(\mathrm{d}_{1}\right)-\mathrm{e}^{-\mathrm{rT}} \cdot \mathrm{F} \cdot \mathrm{N}\left(\mathrm{d}_{2}\right)
$$

where:

E: market price of firm's equity based on stock price and the number of stocks in circulation;

F: debt par value, as proposed by Moody, calculated by short-term debt plus one half of long-term one;

r: instantaneous risk-free interest - government bond interest rate in one-year term; and

$\mathrm{N}($.$) : cumulative standard normal distribution function.$ 
And $\mathrm{d}_{1}$ and $\mathrm{d}_{2}$ are given by:

$$
\begin{aligned}
& \mathrm{d}_{1}=\frac{\ln (V / F)+\left(r+0,5 \sigma_{V}^{2}\right) T}{\sigma_{V} \sqrt{T}} \\
& \mathrm{~d}_{2}=\mathrm{d}_{1}-\sigma_{\mathrm{V}} \sqrt{T}
\end{aligned}
$$

There are two essential functions in KMV-Merton model. One is Black-ScholesMerton function as described earlier, and the other represents correlation between volatility of firm's value and that of its equity. Based on Merton's assumptions and Ito's lemma [3], we have:

$$
\sigma_{\mathrm{E}}=\left(\frac{\mathrm{V}}{\mathrm{E}}\right) \frac{\partial E}{\partial E} \sigma_{\mathrm{V}}=\left(\frac{\mathrm{V}}{\mathrm{E}}\right) \mathrm{N}\left(\mathrm{d}_{1}\right)^{[3]} \sigma_{\mathrm{V}}
$$

where $\sigma_{\mathrm{E}}$ denotes standard deviation of firm's equity.

After $\mathrm{V}$ and $\sigma_{\mathrm{v}}$ are gained from the two nonlinear equations (1) and (2), the distance to default can be calculated as follows:

DD $($ Distance to Default $)=\frac{\ln (V / F)+\left(\mu-0,5 \sigma_{V}{ }^{2}\right) T}{\sigma_{V} \sqrt{T}}$

where $\mu$ denotes annual expected rate of return; and default probability in the model $(\pi \mathrm{KMV})$ is identified by the formula: $\pi \mathrm{KMV}=\mathrm{N}(-\mathrm{DD})$.

Accordingly, when the market price of firm's equity drops, default probability increases. To enable the model to function well, both of the two Merton's assumptions must be satisfied, whereas market operation is effective, reflecting information sufficiently.

\subsection{Some studies developed from KMV-Merton model}

\subsubsection{Typical researches studies}

After the publication of KMV-Merton model, there were quite many studies carried out to evaluate its effectiveness. Most of the researchers focused intensively on two Merton's assumptions and also provided extended versions of the model.

In Bharath's (2004) study, two hypotheses are examined. The first works on whether default probability implied by the Merton model is a sufficient statistic for forecasting bankruptcy. The second assumes that in the KMV-Merton model, functional form of default probability is important whereas results of the two simultaneous nonlinear equations are not critical and can be adjusted in a better manner. 
Through empirical results Bharath finds it easy to reject the first hypothesis and additionally points out a simplified model that is efficient at calculating default probability without relying too much on solving two nonlinear equations required by the classical model. However, in his confirmation of the second hypothesis, Bharath evaluates the volatility of a firm's debt through fixed calculations related to volatility of its equity. This may be equally true for some cases but erroneous for others involving enterprises from different sectors.

In contrast with Bharath (2004), Lu (2008) has certain faith in the likelihood of efficiently calculating default probability with Merton model and thereby develop KMV-Merton model based on the argument that firm's debts need be categorized into long- and short-term ones. Thus, default probability is reconsidered as follows:

Default Probability $=1-\mathrm{N}\left(\mathrm{DD}_{\mathrm{S}}\right) \times \mathrm{N}\left(\mathrm{DD}_{\mathrm{L}}\right)$

$$
\begin{aligned}
& \mathrm{DD}_{\mathrm{S}}=\frac{\ln \left(\mathrm{V}_{0} / \mathrm{D}_{\mathrm{S}}\right)+\left(\mu_{\mathrm{V}}-0,5 \sigma_{V}^{2}\right) T_{\mathrm{S}}}{\sigma_{V} \sqrt{T_{\mathrm{S}}}} \\
& \mathrm{DD}_{\mathrm{L}}=\frac{\ln \left[\frac{\mathrm{V}_{\mathrm{TS}_{\mathrm{S}}}-\mathrm{D}_{\mathrm{S}}}{\mathrm{D}_{\mathrm{L}}}\right]+\left(\mu_{\mathrm{V}}-0,5 \sigma_{V}^{2}\right)\left(T_{\mathrm{L}}-T_{\mathrm{S}}\right)}{\sigma_{V}\left(T_{\mathrm{L}}-T_{\mathrm{S}}\right)}
\end{aligned}
$$

where:

$D_{\text {s: }}$ short-term debt

$\mathrm{T}_{\mathrm{s}}$ : time-to-maturity for short-term debt

$\mathrm{D}_{\mathrm{L}}$ : long-term debt

$\mathrm{T}_{\mathrm{L}}$ : time-to-maturity for long-term debt

Lu's findings suggest significant impact of both long- and short-term debt. However, this research only focuses on firms with both classes of debts and is appropriate for firm rankings rather than calculating default probability due to remaining 'attached' to Merton's first key assumption (firm's total asset can be described by Geometric Brownian Motion).

\subsubsection{Studies conducted in Vietnam}

To date no complete research into KMV model has ever been conducted in Vietnam. The term 'complete' in this case emphasizes an in-depth study that works on the classical KMV and develop a new one commonly applied and best suited to the context of Vietnam. Most of the published papers, such as Lam and Phan (2009) and Le and Le 
(2012), concerning the model actually employ the extension of it, available for explaining one certain phenomenon occurring in the bank system as well as Vietnam's financial market in the past crisis.

Lam and Phan (2009) employ KMV model to quantify credit risk in the use of collateral associated with borrower's behavior via surveying impacts of such variables as ratio of maximum loan to collateral, borrower's intentions of using loan and number of times borrowers use assets formed by loan capital as collateral. From the quantitative results achieved the research team forecasts the underlying credit risk in supply of loan based on real estate mortgage by commercial banks in particular and in credit markets in general. However, this study only provides arguments without any specific verification (for the case of a specific bank) of its proposed approach.

Le and Le (2012) attempt to combine CVaR and KMV-Merton model to estimate default risk in Vietnam's financial market through empirical evidence before and after 2008. In fact, such combination is not new since it has already been applied by Powell and Allen (2007) with empirical evidence from enterprises listed in Australian stock market producing positive outcomes. CVaR, a method developed from VaR, aims to assess the possibility (at a certain level of reliability) that a specific loss would exceed the value of risk (VaR).

This research also proposes the advantages of CVaR compared to those of $\mathrm{VaR}$, such that the former offers the calculation of the volume of losses in the tail of distribution. Thence, it proceeds with the combination of CVar and KMV-Merton model by establishing conditional probability of default (CPD), i.e. default probability based on the conditions that the standard deviation of returns on assets exceeds the common standard deviation at $95 \%$ level of reliability. Although Le and Le's (2012) study yields highly significant findings, it underscores the demonstration of effectiveness in calculating 'escaped' default probability together with examples from the two cycles before and after the crisis without offering particular applications at a specific time and/or for a specific bank, about which bank managers are genuinely concerned.

Other researches, furthermore, use Z-Score model proposed by Altman (1968), and subsequently ZETA to assess determinants of default probability. Yet, each has different pros and cons. While Altman's Z-Score bases itself on multiple discriminant analysis (MDA) (independent variables are financial indicators affecting default probability, and 
dependent ones, applied to default and non-default enterprises, take values of 1 and 0 respectively), KMV model generally measures volatility of firm's debt through calculations related to volatility of firm's equity on the basis of functions connected with default probability and expected loss.

Regression coefficients of the Z-Score model, which was developed in a research on US manufacturing firms, will be altered when it is adapted to the Vietnam's context. Moreover, it is difficult to gather actual data from bankrupt enterprises in Vietnam to calculate the coefficients or scores on the possibility of firm's default. In fact, researchers may apply various models and then compare the results. If the results achieved from the models share certain similarity, this will confirm high reliability of the estimation.

To sum up, a review of the existing studies as well as their applicability in practice reveals that Z-Score seems to be more widely applicable than KVM due to its regression coefficients already calculated in advance and the previous scale corresponding to each coefficient. Yet, to compare results from the two models, both must be tested, and thus further studies on the application of Z-Score and KVM models to the same enterprise in Vietnam are needed. Within this paper, the authors only address KVM model and its applicability in Vietnam.

\section{Methodology}

The paper, in consideration of previous studies and data collection in Vietnam, employs KMV-Merton (Equation 1), Lu's (2008) model (Equation 3) with appropriate adjustments that best features Vietnam's traits. Due to the fact that only a small proportion of enterprises are listed on stock market, the authors propose a detailed calculation suiting the assessment of credit risk for corporate customers' portfolios including both listed and unlisted ones.

Initially, the first nonlinear equation of KMV-Merton model (Equation 1) is used for calculating market price of enterprise (V)'s assets:

$\mathrm{E}=\mathrm{V} \cdot \mathrm{N}\left(\mathrm{d}_{1}\right)-\mathrm{e}^{-\mathrm{rT}} \cdot \mathrm{F} \cdot \mathrm{N}\left(\mathrm{d}_{2}\right)$

where:

E: firm's equity is calculated based on financial statement data; 
$\mathrm{d}_{1}=\frac{\ln \left(V^{*} / F\right)+\left(r+0,5 \sigma_{V}^{2}\right) T}{\sigma_{V} \sqrt{T}}$ where $\mathrm{V}^{*}$ is firm's assets as defined in financial statements and $\sigma_{\mathrm{V}}$ is the standard deviation of firm's assets based on volatility of firm's assets during the four years (2008-2012);

$\mathrm{d}_{2}=\mathrm{d}_{1}-\sigma_{\mathrm{V}} \sqrt{T}$ where $\mathrm{T}$ is time when default probability is considered (usually one year).

In case volatility of firm's assets cannot be measured in market price as many medium- and small-sized enterprises are not qualified to be listed, we calculate the volatility through standard deviation of asset volatility in four years based on financial statement data. The basis of standard deviation selected for calculations is based on previous studies in developing countries, as in Bharath (2004).

Bharath's and other studies showcase empirical evidence that volatility of firm's assets according to book value is positively related to volatility of equity's market price or firm's stock price in the market. According to Bharath (2004), the variables of the above equation may definitely be changed to act in accordance with actuality without much influence on the results of default probability function. Nevertheless, this requires further empirical evidence, particularly in Vietnam's context, to test this argument.

zr: risk-free interest rate - one-year government bond rate $(8.9 \%$ in 2012)

F: face value equaling short-term debt plus one half of long-term debt

After calculating the market price of firm's assets, we, in the next step, estimate distance to default and default probability based on Equation 1 of the classical KMVMerton model. Next, after default probability of each firm is found, default probability of the portfolio is measured by the following equation:

$$
\mathrm{DP}_{\text {portfolio }}=\sqrt{w_{i}^{2} * D P_{i}^{2}},
$$

where $\mathrm{w}_{\mathrm{i}}$ is proportion of firm $i$ 's outstanding loans compared to total loans of the whole portfolio and $\mathrm{DP}_{\mathrm{i}}$ is default probability of firm $i$.

Based on the formula for losses caused by bankruptcy of corporate customers defined by Basel II, losses caused by bankruptcy of each corporate customer for the bank could be determined by:

$$
\mathrm{EL}=\mathrm{N}(-\mathrm{DD}) \times\left(\mathrm{F}-\mathrm{V}_{0} \mathrm{e}^{[-\mathrm{rT}]} \frac{\mathrm{N}\left(-\mathrm{DD}^{*}\right)}{\mathrm{N}(-\mathrm{DD})}\right) \times \frac{E A D}{F}
$$

where: 
EL: expected loss;

DD: distance to default $\left(\mathrm{DD}^{*}=\mathrm{DD}+\sigma \mathrm{V} \sqrt{T}\right)$;

F: total debt (short-term debt plus $50 \%$ of long-term one);

V: firm's assets;

EAD: surveyed bank's exposure at default;

r: firm's expected return on assets;

$\mathrm{T}$ : time to maturity regarded within one year.

\section{Data description}

The data used in the research are from the financial statements by corporate customers of Vietcombank between 2008 and 2012 with a total of 6,638 enterprises listed in loan portfolio and the total outstanding loan to the portfolio of VND166,185.998 billion by the end of 2012. Corporate customers are divided into four groups according to their size as illustrated in Table 1 below:

\section{Table 1}

Classification of corporate customers

\begin{tabular}{llcc}
\hline \multicolumn{1}{c}{ Size } & \multicolumn{1}{c}{ Total assets } & Customers & $\begin{array}{c}\text { Proportion of } \\
\text { outstanding loans }\end{array}$ \\
\hline Very small & Less than VND30 bil. & 2,546 & $3.65 \%$ \\
Small & From VND30 to 65 bil. & 1,925 & $11.73 \%$ \\
Medium & From VND65 to 180 bil. & 944 & $14.44 \%$ \\
Large & Over VND180 bil. & 983 & $70.18 \%$ \\
\hline
\end{tabular}

Source: Vietcombank's by-laws

Those 6,398 corporate customers are also divided by Vietcombank's by-laws into 52 categories according to their industries as shown in Table 6 .

Table 2 illustrates several indexes from financial statements of corporate customers used for calculations. 


\section{Table 2}

Statistical description of financial information of firms listed in 2012-2013's loan portfolio (VND billion \& \%)

\begin{tabular}{lccccc}
\hline & Total assets & $\begin{array}{c}\text { Surveyed bank's } \\
\text { EAD }\end{array}$ & Equity & Profit after tax & $\begin{array}{c}\text { ROA } \\
(\%)\end{array}$ \\
\hline Total & $3,263,605$ & 166,185 & $1,084,473$ & 121,646 & $3.7 \%$ \\
Max & $577,601.066$ & $10,732.596$ & $263,800.964$ & 34,383 & $5.9 \%$ \\
Min & 0.333 & 0.105 & 0.108 & $-9.326^{*}$ & $-11.5 \%$ \\
Mean & 510.097 & 25.974 & 169.487 & 19.025 & $3.7 \%$ \\
\hline
\end{tabular}

Note: * denotes that firm with the lowest profit after tax has total assets of VND80,828 bil.

Source: Financial statement data of corporate customers at Vietcombank - Calculations from Crystal Ball

\section{Research Results}

\subsection{Assessment of the whole portfolio}

The results of the default-probability estimations in enterprises in the whole portfolio are represented in Table 3 . These demonstrate a very low chance of default occurring $2.6 \%$, which implies that the bank's governance, management and control of credit risk concerning corporate customer loan portfolio is quite rational. Due to a high proportion of loans, the bank's loss within a year with probability of default of $2.6 \%$ to the whole portfolio of corporate customers is not small (VND6,319.35 billion), accounting for $3.8 \%$ of loan outstanding balance (VND6,319.35 bil./166,185 bil.).

\section{Table 3}

Default probability of enterprises in the whole portfolio and losses caused by default customers

\begin{tabular}{lcl}
\hline Statistical index & $\begin{array}{l}\text { Default probability } \\
\text { of enterprises }\end{array}$ & Notes \\
\hline Obs. & 6.398 & 6,398 surveyed enterprises \\
Mean & $24 \%$ & $\begin{array}{l}\text { Mean of firms' default probability is } 24 \% \text { (for } \\
\text { reference only and not useful for calculations in the } \\
\text { study). }\end{array}$ \\
\hline
\end{tabular}


Table 3 (continued)

\begin{tabular}{lll}
\hline Statistical index & $\begin{array}{l}\text { Default probability } \\
\text { of enterprises }\end{array}$ & Notes \\
\hline Median & $9 \%$ & $\begin{array}{l}\text { The median represents half the number of } \\
\text { observations }(3,199 \text { enterprises) with default } \\
\text { probability of below } 9 \% \text { and the other half }(3,199 \\
\text { enterprises) with default probability of over } 9 \% .\end{array}$ \\
$\begin{array}{l}\text { Minimum } \\
\text { Maximum }\end{array}$ & $\begin{array}{l}\text { Minimum default probability is } 0 \% . \\
\text { Default probability } \\
\text { of the whole } \\
\text { portfolio }\end{array}$ & Maximum default probability is $100 \%$. \\
$\begin{array}{l}\text { Losses of the } \\
\text { whole portfolio }\end{array}$ & VND6,319.35 bil. & \\
\hline
\end{tabular}

Source: Authors' calculations based on Crystal Ball and Excel

The estimations of expected loss for each group of enterprises according to the level of default probability are illustrated in Table 4 . The results indicate that enterprises with default probability of less than $10 \%$ account for $50 \%$, whereas those with default probability of over 50\% (1,444 enterprises) account for approximately 25\% of enterprises in the portfolio. Particularly, the total number of enterprises with default probability of $100 \%$ is 55, coming up with expected loss of VND413.065 billion, which is deemed not a small loss to the bank.

\section{Table 4}

Enterprises by Default Probability

\begin{tabular}{lcc}
\hline \multicolumn{1}{c}{ Default probability } & Enterprises & Expected loss (VND billion) \\
\hline Below 10\% & 3,257 & 542.719 \\
$10-20 \%$ & 514 & 177.918 \\
$20-30 \%$ & 387 & 197.035 \\
$30-40 \%$ & 390 & 415.413 \\
$40-50 \%$ & 406 & 597.673 \\
$50-60 \%$ & 407 & $1,012.517$ \\
\hline
\end{tabular}


Table 4 (continued)

\begin{tabular}{lcc}
\hline \multicolumn{1}{c}{ Default probability } & Enterprises & Expected loss (VND \\
\hline $60-70 \%$ & 395 & 881.409 \\
$70-80 \%$ & 336 & $1,203.026$ \\
$80-90 \%$ & 176 & 591.180 \\
$90-$ below 100\% & 75 & 287.393 \\
$100 \%$ & 55 & 413.065 \\
The whole portfolio & 6.398 & $6,319.35$ \\
\hline
\end{tabular}

Source: Calculations based on Vietcombank's internal data

5.2. Assessment by size

\section{Table 5}

Default probability and expected loss by enterprise size

\begin{tabular}{lcccc}
\hline \multicolumn{1}{c}{ Size } & Enterprises & $\begin{array}{c}\text { Distribution } \\
\text { of outstanding } \\
\text { loans to } \\
\text { total loans }\end{array}$ & $\begin{array}{c}\text { Default probability } \\
\text { (portfolio weighted } \\
\text { average yield } \\
\text { calculation based on } \\
\text { Eq. 4) (\%) }\end{array}$ & $\begin{array}{c}\text { Expected loss } \\
\text { (VND billion) }\end{array}$ \\
\hline Very small & 2,546 & $3.65 \%$ & $2.033 \%$ & 402.11 \\
Small & 1,925 & $11.73 \%$ & $2.164 \%$ & $1,405.49$ \\
Medium & 944 & $14.44 \%$ & $2.986 \%$ & $1,583.27$ \\
Large & 983 & $70.18 \%$ & $3.637 \%$ & $2,928.47$ \\
Entire portfolio & 6,398 & $100 \%$ & $2.6 \%$ & $6,319.35$ \\
\hline
\end{tabular}

Source: Calculations based on Vietcombank's internal data

Tables 1 and 5 illustrate that corporate customer loan portfolio mainly falls into the groups of small- and very-small-sized enterprises (accounting for over $65 \%$ of the portfolio) and both feature default probability being lower than the other two groups of medium- and large-sized ones. Particularly, very-small-sized enterprises reveal the lowest default probability (2.033\%), and next come small-sized ones $(2.164 \%)$. While large-sized enterprises reveal the highest default probability (3.637\%), medium-sized ones come up with the second highest $(2.986 \%)$, and these two groups also cause the most massive losses to the bank - VND2,928.47 billion and VND1,583.27 billion respectively. 


\subsection{Assessment by industry}

Table 6 represents the results of default probability estimations and expected losses by industries (a total of 55 industries according to the bank's classification). The results suggest that road and waterway transport reveals the lowest default probability $(0.3 \%)$. This is the industry from which a relatively large number of corporate customers come, ranking $6^{\text {th }}$ out of 52 industries (251 enterprises in total, and most of them are smallsized ones with low outstanding loans). The highest default probability (6.9\%) is found in production, transmission, and distribution of electricity and other kinds of energy. This is understandable because a large number of enterprises from this industry in the portfolio are large-sized ones with high outstanding loans due to their demand for capital at the early stage of production. This results in the bank's expected loss (caused by production, transmission, and distribution of electricity and other kinds of energy) of VND197.480. billion, accounting for 3.13\% of total expected loss of the whole portfolio.

The calculations also show that shipbuilding industry has the lowest expected loss of VND0.113 billion. The industry is typical of the least number of enterprises (5) out of 52 industries. Seafood processing business is marked by the highest expected loss of VND632.502 billion, accounting for $10.01 \%$ of total expected loss even though the industry's default probability is $1.7 \%$ (Table 6). The reason why it causes high loss to the bank is its high proportion of loans $(6.29 \%)$ compared to others.

\section{Table 6}

Default probability and expected loss by industries

\begin{tabular}{clcccc}
\hline No & \multicolumn{1}{c}{ Industry } & Enterprises & $\begin{array}{c}\text { Sectoral } \\
\text { distribution } \\
\text { of outstandi } \\
\text { ng loans to } \\
\text { total loans }\end{array}$ & $\begin{array}{c}\text { DP (portfolio } \\
\text { weighted } \\
\text { average yield } \\
\text { calculation } \\
\text { based on Eq. } \\
4)(\%)\end{array}$ & $\begin{array}{c}\text { Expected } \\
\text { loss } \\
\text { (VND }\end{array}$ \\
\hline 1 & Farmillion) \\
2 & Animal husbandry & 36 & $0.35 \%$ & $0.42 \%$ & 4.605 \\
3 & Aquaculture & 29 & $0.10 \%$ & $0.32 \%$ & 24.719 \\
4 & $\begin{array}{l}\text { Coal mining and associated } \\
\text { services }\end{array}$ & 24 & $0.28 \%$ & $0.84 \%$ & 11.536 \\
\hline
\end{tabular}


Table 6 (continued)

\begin{tabular}{|c|c|c|c|c|c|}
\hline No & Industry & Enterprises & $\begin{array}{l}\text { Sectoral } \\
\text { distribution } \\
\text { of outstandi } \\
\text { ng loans to } \\
\text { total loans }\end{array}$ & $\begin{array}{l}\text { DP (portfolio } \\
\text { weighted } \\
\text { average yield } \\
\text { calculation } \\
\text { based on Eq. } \\
\text { 4) }(\%)\end{array}$ & $\begin{array}{l}\text { Expected } \\
\text { loss } \\
\text { (VND } \\
\text { billion) }\end{array}$ \\
\hline 5 & $\begin{array}{l}\text { Oil and natural gas mining } \\
\text { and associated services }\end{array}$ & 17 & $5.76 \%$ & $0.87 \%$ & 14.565 \\
\hline 6 & $\begin{array}{l}\text { Exploitation of other } \\
\text { minerals }\end{array}$ & 61 & $0.57 \%$ & $0.32 \%$ & 22.339 \\
\hline 7 & $\begin{array}{l}\text { Processed food (except } \\
\text { seafood) and beverage }\end{array}$ & 143 & $3.51 \%$ & $1.98 \%$ & 483.314 \\
\hline 8 & Tobacco \& cigarette & 15 & $1.18 \%$ & $2.50 \%$ & 22.009 \\
\hline 9 & Aquaproduct processing & 150 & $6.29 \%$ & $1.70 \%$ & 632.502 \\
\hline 10 & Fibers and cloth & 74 & $1.56 \%$ & $1.12 \%$ & 102.481 \\
\hline 11 & Apparel and clothing & 142 & $1.60 \%$ & $1.20 \%$ & 78.445 \\
\hline 12 & Leather and footwear & 38 & $1.02 \%$ & $1.38 \%$ & 71.256 \\
\hline 13 & $\begin{array}{l}\text { Wood exploitation and } \\
\text { processing/ furniture }\end{array}$ & 280 & $2.86 \%$ & $0.73 \%$ & 284.300 \\
\hline 14 & Pulp and paper product & 116 & $1.30 \%$ & $1.28 \%$ & 55.307 \\
\hline 15 & $\begin{array}{l}\text { Pharmaceuticals and } \\
\text { chemical medicines }\end{array}$ & 42 & $0.68 \%$ & $0.81 \%$ & 34.129 \\
\hline 16 & Electrical appliances & 53 & $0.97 \%$ & $0.55 \%$ & 22.912 \\
\hline 17 & $\begin{array}{l}\text { Electronic equipment, } \\
\text { computer, optical product } \\
\text { and medical devices and } \\
\text { equipment }\end{array}$ & 22 & $0.27 \%$ & $0.39 \%$ & 6.283 \\
\hline 18 & Animal feed & 73 & $2.28 \%$ & $1.50 \%$ & 154.905 \\
\hline
\end{tabular}


Table 6 (continued)

\begin{tabular}{|c|c|c|c|c|c|}
\hline No & Industry & Enterprises & $\begin{array}{l}\text { Sectoral } \\
\text { distribution } \\
\text { of outstandi } \\
\text { ng loans to } \\
\text { total loans }\end{array}$ & $\begin{array}{l}\text { DP (portfolio } \\
\text { weighted } \\
\text { average yield } \\
\text { calculation } \\
\text { based on Eq. } \\
\text { 4) }(\%)\end{array}$ & $\begin{array}{l}\text { Expected } \\
\text { loss } \\
\text { (VND } \\
\text { billion) }\end{array}$ \\
\hline 19 & $\begin{array}{l}\text { Fertilizer, plastic resin, } \\
\text { synthetic rubber, and other } \\
\text { basic chemicals }\end{array}$ & 97 & $1.48 \%$ & $1.30 \%$ & 117.799 \\
\hline 20 & Steel billet & 14 & $2.27 \%$ & $3.29 \%$ & 227.249 \\
\hline 21 & Rolled steel & 56 & $3.03 \%$ & $1.59 \%$ & 132.295 \\
\hline 22 & $\begin{array}{l}\text { Automobile/motorcycle } \\
\text { assembling and } \\
\text { manufacturing }\end{array}$ & 18 & $1.00 \%$ & $1.17 \%$ & 49.389 \\
\hline 23 & Mechanical engineering & 155 & $1.59 \%$ & $0.55 \%$ & 92.775 \\
\hline 24 & Shipbuilding & 5 & $0.08 \%$ & $2.11 \%$ & 0.113 \\
\hline 25 & Cement & 18 & $2.83 \%$ & $2.09 \%$ & 52.146 \\
\hline 26 & Tile, brick and paver & 90 & $0.92 \%$ & $0.64 \%$ & 36.561 \\
\hline 27 & $\begin{array}{l}\text { Other metal (except steel) } \\
\text { and nonmetal (except } \\
\text { cement, brick, tile, and } \\
\text { paver) products }\end{array}$ & 58 & $0.73 \%$ & $0.43 \%$ & 40.188 \\
\hline 28 & $\begin{array}{l}\text { Production, transmission, } \\
\text { and distribution of electricity } \\
\text { and other kinds of energy }\end{array}$ & 30 & $8.70 \%$ & $6.90 \%$ & 197.480 \\
\hline 29 & $\begin{array}{l}\text { Construction, assembly } \\
\text { works and associated } \\
\text { consultancy services }\end{array}$ & 866 & $5.63 \%$ & $1.70 \%$ & 289.786 \\
\hline
\end{tabular}


Table 6 (continued)

\begin{tabular}{|c|c|c|c|c|c|}
\hline No & Industry & Enterprises & $\begin{array}{c}\text { Sectoral } \\
\text { distribution } \\
\text { of outstandi } \\
\text { ng loans to } \\
\text { total loans }\end{array}$ & $\begin{array}{l}\text { DP (portfolio } \\
\text { weighted } \\
\text { average yield } \\
\text { calculation } \\
\text { based on Eq. } \\
\text { 4) }(\%)\end{array}$ & $\begin{array}{c}\text { Expected } \\
\text { loss } \\
\text { (VND } \\
\text { billion) }\end{array}$ \\
\hline 30 & $\begin{array}{l}\text { Real estate (houses, } \\
\text { apartment houses, urban } \\
\text { clusters, etc.) }\end{array}$ & 32 & $3.20 \%$ & $1.80 \%$ & 120.756 \\
\hline 31 & $\begin{array}{l}\text { Real estate for rent (offices, } \\
\text { trade centers, apartments, } \\
\text { etc.) }\end{array}$ & 30 & $0.30 \%$ & $0.68 \%$ & 15.504 \\
\hline 32 & $\begin{array}{l}\text { Services for industrial parks } \\
\text { and export processing zones }\end{array}$ & 16 & $0.57 \%$ & $0.50 \%$ & 4.897 \\
\hline 33 & $\begin{array}{l}\text { Trade in industrial and } \\
\text { construction materials } \\
\text { (except oil and gas) }\end{array}$ & 661 & $5.68 \%$ & $1.09 \%$ & 558.612 \\
\hline 34 & $\begin{array}{l}\text { Petroleum oil and gas } \\
\text { trading }\end{array}$ & 246 & $4.49 \%$ & $3.21 \%$ & 214.648 \\
\hline 35 & Consumer goods trading & 755 & $3.92 \%$ & $2.51 \%$ & 470.226 \\
\hline 36 & Rice trading & 120 & $2.47 \%$ & $1.49 \%$ & 276.690 \\
\hline 37 & Coffee trading & 74 & $1.11 \%$ & $2.09 \%$ & 134.093 \\
\hline 38 & $\begin{array}{l}\text { Agricultural materials } \\
\text { trading }\end{array}$ & 80 & $1.18 \%$ & $1.56 \%$ & 111.843 \\
\hline 39 & Other farm products trading & 216 & $2.06 \%$ & $0.87 \%$ & 217.033 \\
\hline 40 & Sea transport & 48 & $2.30 \%$ & $0.83 \%$ & 29.040 \\
\hline 41 & $\begin{array}{l}\text { Road and waterway } \\
\text { transport }\end{array}$ & 251 & $0.93 \%$ & $0.30 \%$ & 34.968 \\
\hline 42 & Air transport & 2 & $0.80 \%$ & $2.61 \%$ & 1.342 \\
\hline
\end{tabular}


Table 6 (continued)

\begin{tabular}{|c|c|c|c|c|c|}
\hline No & Industry & Enterprises & $\begin{array}{c}\text { Sectoral } \\
\text { distribution } \\
\text { of outstandi } \\
\text { ng loans to } \\
\text { total loans }\end{array}$ & $\begin{array}{l}\text { DP (portfolio } \\
\text { weighted } \\
\text { average yield } \\
\text { calculation } \\
\text { based on Eq. } 4 \text { ) } \\
\qquad \%)\end{array}$ & $\begin{array}{c}\text { Expected } \\
\text { loss } \\
\text { (VND } \\
\text { billion) }\end{array}$ \\
\hline 43 & $\begin{array}{l}\text { Warehousing and port services } \\
\text { / other transport support } \\
\text { activities }\end{array}$ & 58 & $0.58 \%$ & $0.59 \%$ & 9.132 \\
\hline 44 & $\begin{array}{l}\text { Accommodation, catering and } \\
\text { recreation services }\end{array}$ & 161 & $1.69 \%$ & $3.16 \%$ & 268.665 \\
\hline 45 & $\begin{array}{l}\text { Information and } \\
\text { communication (except } \\
\text { telecommunication) services }\end{array}$ & 87 & $0.30 \%$ & $0.69 \%$ & 2.830 \\
\hline 46 & Telecommunication services & 61 & $1.29 \%$ & $0.38 \%$ & 18.307 \\
\hline 47 & $\begin{array}{l}\text { Education, training and public } \\
\text { utility services }\end{array}$ & 45 & $0.29 \%$ & $1.76 \%$ & 63.353 \\
\hline 48 & $\begin{array}{l}\text { Healthcare services and } \\
\text { relevant others }\end{array}$ & 21 & $0.19 \%$ & $0.89 \%$ & 3.843 \\
\hline 49 & $\begin{array}{l}\text { Manufacture of other consumer } \\
\text { goods (except textiles, apparel, } \\
\text { leather and footwear, furniture, } \\
\text { paper products and home } \\
\text { electronic and electrical } \\
\text { appliances) }\end{array}$ & 218 & $4.04 \%$ & $0.89 \%$ & 296.913 \\
\hline 50 & $\begin{array}{l}\text { Water supply, sewerage and } \\
\text { waste treatment }\end{array}$ & 15 & $0.08 \%$ & $0.38 \%$ & 6.067 \\
\hline 51 & $\begin{array}{l}\text { Consultancy and support } \\
\text { services }\end{array}$ & 37 & $0.12 \%$ & $0.32 \%$ & 3.486 \\
\hline 52 & $\begin{array}{l}\text { Trade in transport means, } \\
\text { machinery, equipment and } \\
\text { accessories }\end{array}$ & 384 & $1.90 \%$ & $0.66 \%$ & 161.135 \\
\hline & The whole portfolio & 6.398 & $100 \%$ & $2.6 \%$ & $6,319.35$ \\
\hline
\end{tabular}

Source: Calculations based on Vietcombank's internal data 


\section{Conclusions and recommendations}

\subsection{Conclusions}

The estimation results of corporate customer probability of default and bank's expected loss due to credit risk based on the KMV-Merton model support bank's managers with customer risk rating by size and industry categories, and measurement of losses that may occur under customer's insolvency due to high default risks. The results indicate that in spite of not too high default probability to the whole corporate customer portfolio (2.6\%), the expected loss resulting from customer risks accounts for approximately $3.8 \%$ of bank's total loans. The figure also complies with bank's current bad debt ratio (lower than the average rate of the banking sector with a bad debt ratio of 5-6\%). However, high default probability is revealed by large-sized enterprises as well as industries with high concentration of credit (those characterized by large number of enterprises and outstanding loans).

\subsection{Recommendations}

The case study of corporate customers of such a big bank as Vietcombank allows the following recommendations for commercial banks:

First, Vietnam's commercial banks may apply various tools to forecast customer default risk based on KMV-Merton model, which facilitates bank's risk management and supports it with measures to prevent and avoid massive losses caused by customers with high default risks.

Second, the employment of econometrical models to forecast default risks requires adequate statistics and customer data through financial statements, the status of outstanding loans and expected loans from different sources. Within current information constraints commercial banks need to form centers for storing customer information and audited financial statements over years.

Additionally, there should be collaboration with SBV credit information centers to ensure sufficient and reliable supply of information on outstanding loans and the customer's existing loans. The insufficiency and unreliability result in many regrettable incidents such as a corporate customer applies for loans at various banks with the same mortgage records.

The first condition for the application of KMV-Merton is fully updated customer information, audited financial statements, credit information connected between the banks so the customer's actual outstanding loans can be well grasped by different banks, thereby 
accurately estimating the corporate customer's debt ratio to each bank which is the basis for calculating the expected loss caused by a customer default risk.

In developed countries, information about firm's financial statements and loan capital are fully updated and transparent. Meanwhile, Vietnam is in the process of international integration and commits to BASEL regulations; thus, it is important that regulations on information disclosure be compliant with international standards. Challenging as the case should be, it is to be conducted, and to improve the system of credit information calls for stipulations clearly defined by SBV.

Third, concerning particular modern tools in credit risk management, commercial banks need a team of experts capable of applying econometrical models as well as data processing software. Actually, international experience shows that well-trained expertise is needed to handle financial mathematics and that the banks with sound risk management are those having good staff in the department of risk management, who are intensively trained in financial mathematics and are competent in setting up data processing software, performing risk estimations based upon different techniques, and making analyses of estimation results as well as forecasts for risk in alternative scenarios.

Furthermore, small-sized banks without the contribution of professional experts are highly recommended to work in conjunction with the researchers from colleges or academic institutions, applying modern techniques as mentioned above. Accordingly, such completion of information system and rational exploitation of human potentials, correspondingly qualified, are prerequisites for the application of mathematical models in general and KMVMerton model in particular to the forecasts for credit risks and bank's expected losses, which allow for sound solutions to prevent risks and minimize losses

\section{Note}

[1] The data for corporate customer portfolio are to the end of 2013 but the data from financial statements audited as for 6,398 enterprises are only to the end of 2012 (financial statement audit in Vietnam is as usual one year lag); corporate customers' names were kept confidential in that only firm codes, industry codes, and financial statistics based on financial statements in accordance with each firm code were provided.

[2] Wiener process is a continuous-time stochastic process characterized by three properties: $1 / \mathrm{dW} 0=0$; $2 /$ the function $\mathrm{t} \rightarrow \mathrm{dWt}$ is almost surely everywhere continuous; $3 / \mathrm{dWt}$ has independent increments with $\mathrm{dWt}-\mathrm{dWs} \sim \mathrm{N}(0, \mathrm{t}-\mathrm{s})$ (for $0 \leq \mathrm{s}<\mathrm{t}$ ), where $\mathrm{N}(\mu, \sigma 2)$ denotes the normal distribution with expected value $\mu$ and variance $\sigma 2$. The last condition means that if $0 \leq \mathrm{s} 1<\mathrm{t} 1 \leq \mathrm{s} 2<\mathrm{t} 2$ then $\mathrm{dWt} 1-$ $\mathrm{dWs} 1$ and $\mathrm{dWt} 2-\mathrm{dWs} 2$ are independent random variables. 
[3] Lemma applied to the calculations to find the differential of a time-dependent function of a stochastic process

\section{References}

Allen, D. E., \& Powell, R. J. (2007). Thoughts on VaR and CvaR. In L. Oxley \& D. Kulasiri (Eds.), MODSIM 2007 International conference on modelling and simulation (pp. 1843-1850). Perth, Australia: Modelling and Simulation Society of Australia and New Zealand. Retrieved from http://www.mssanz.org.au/MODSIM07/papers/29_s1/ThoughtsOnVar_s1_Allen_.pdf.

Allen, D. E., \& Powell, R. J. (2008). Structural credit modelling and its relationship to market value at risk: An Australian sectoral perspective (School of Accounting, Finance and Economics \& FEMARC Working Paper Series: Working Paper 0801). Perth, Australia: Edith Cowan University. Retrieved February 18, 2012 from https://www.ecu.edu.au/_data/assets/pdf_file/0019/40654/wp0801da.pdf.

Altman, E. I. (1968). Financial ratios, discriminant analysis and the prediction of corporate bankruptcy. The Journal of Finance, 23(4), 589-609.

Avellaneda, M., \& Zhu, J. (2001). Modelling the distance-to-default process of a firm. Risk, 14(12), 125129.

Bharath, S. T., \& Shumway, T. (2004, March). Forecasting default with the KMV-Merton model. AFA 2006 Boston Meetings Paper, Boston, MA. Retrieved from http://ssrn.com/abstract=637342.

Black, F. \& Scholes, M. (1973). The pricing of options and corporate liabilities. Journal of Political Economy, 81, 637-659.

Capuano, C., Chan-Lau, J., Gasha, G., Medeiros, C., Santos, A., \& Souto, M. (2009). Recent advances in credit risk modeling (IMF Working Paper WP/09/162). Washington DC: International Monetary Fund..

Hull, J. C. (2002). Options, futures, and other derivatives (5th ed.). Hoboken, NJ: Prentice Hall.

Lam, C. D., \& Phan, D.A. (2009). Application of KMV- Merton model to the quantification of relations between the assets guarantee, the borrower's funds apportionment and the credit risk (in Vietnamese). Science-Technology Journal - University of Danang, 31, 1-6.

Le, D. C., \& Le, T. A. (2012). Combining CVaR and Merton/KMV model to measure default risk: Empirical evidence from Vietnam (in Vietnamese). Journal of Development and Integration, 5(15), $10-15$.

Lu, Y. (2008). Default forecasting in KMV (Unpublished master's thesis). University of Oxford, UK.

Merton, R. C. (1974). On the pricing of corporate debt: The risk structure of interest rates. Journal of Finance, 29, 449-470.

Vasicek, O. A. (1987). Probability of loss on loan portfolio. San Francisco: KMV Corporation.

Wiener process. (2012) Wikipedia, the free encyclopedia. Retrieved February 18, 2012 from http://en.wikipedia.org/wiki/Wiener_process. 